VOL. 03 NO. 01, JUNE 2021

\title{
Grammatical Interference in English Communication Used by Nurul Jadid Students
}

\author{
Durratul Hikmah ${ }^{1}$, M. Iskandar Dzulqarnain ${ }^{2}$, Sulton Arifin ${ }^{3}$ \\ Universitas Nurul Jadid \\ durrohhikmah@unuja.ac.id ${ }^{1}$, iskandardzulkarnain109@gmail.com², nilaatnaanjani@gmail.com ${ }^{3}$
}

\begin{abstract}
Interference is one of the factors that can undermine a language system. Generally, interference often occurs in language learning process. The interference is caused by a tendency to accustom the pronunciation of one language to another. Its scope includes changes in sound form, grammar, sentence structure, and vocabulary. Nurul Jadid Islamic boarding school is one of the boarding schools that develops foreign language skills as an attempt to prepare young people to be able to compete in the global world. In fact, the language learners (santri) still often mix the structure of their first language into foreign languages to communicate. Therefore, this study aims to identify the grammatical interference in the foreign language communication of Nurul Jadid students, and what factors behind them. The research method used is descriptive qualitative. The results show that the form of interference in Nurul Jadid students' communication is in the form of morphological and syntactical structure. Besides, these interferences are caused by several factors; they are learners' bilingualism, language loyalty, synonymy necessity and the learner's habit in using first language. This research is expected to provide information to language teachers, so that they can find learning innovations that can improve the quality of foreign language skills of Nurul Jadid's students.
\end{abstract}

Keywords: Grammar, first language, interference, English communication

\section{INTRODUCTION}

Nurul Jadid is one of the influential boarding schools in East Java which is located in Paiton, Probolinggo. Probolinggo and its surrounding are considered culturally special due to the most dominant language used is Javanese-Probolinggo or Javanese-Madura dialect (BJM) as the sociocultural identity of the speaking community (Sugeha, 2017). This is due to the large number of Madurese and Javanese tribes who live in this area. The exchange of language codes used by both tribes makes Probolinggo people are more familiar with Madurese dialect. This incident certainly affects the language used by people who live nomadically or permanently in this area, including the students at Nurul Jadid Islamic boarding school.

Nurul Jadid is a boarding school that is aggressive towards the current issues (Razaq, 2019). It can be shown by the provision of students with foreign language education which is centralized in several foreign language institutions, such as FLDI, LIPS, BPK, MAK, KSK, and many others. The students in these institutions are required to speak in foreign language for their daily communication. The language is based on their concentration in each institution. English is the foreign language that is most in demand to be studied at some institutions because it is considered as the first international language used to interact with other people around the world. However, the English used is a kind of language being interfered by students' first language. This makes people strange to hear it.

Speaking in English can be a challenging task for language learners who do not have good command on the language (Tom, Johari, Rozaimi, \& Huzaimah, 2013). In line with this, (Shumin, 2002) in (Abrar, Mukminin, \& Habibi, 2018) stated that speaking in a foreign language requires a high complex skills. To communicate in a foreign language, a speaker is 


\section{VOL. 03 NO. 01, JUNE 2021}

required to have proper linguistics, sociolinguistics, and rhetorical competencies. The linguistics competence includes the speaker's language proficiency, such as grammar, vocabulary and pronunciation. Sociolinguistics competence requires the speaker's ability to recognize the interpretation of meaning in different language contexts, and rhetorical competence entails the mastery of conveying the relevant messages to reach the purpose of speech (Abrar, Mukminin, \& Habibi, 2018). Ur (1996) in (Abrar, Mukminin, \& Habibi, 2018) pointed four common factors that causes difficulties in speaking foreign language; they are inhibition (such as worrying about making mistakes, being fearful to be criticized, and being shy), nothing to say, low participation, and mother tongue use. Mother tongue use means the use of the speaker's dialect, vocabulary, pronunciation, and sentence rule when speaking in other language. Those difficulties can cause an interference in language speaking.

Interference often happens to foreign language learners as the consequence of the degree to which their first language differs from the targeted language. The language learners generally produce errors on syntax, word diction, and pronunciation that is influenced by their first language. The language interference is understood as the inclusion of first language elements into the targeted language, so it changes the targeted language structures. Moreover, (Vavilova, Korneeva, \& Quy, 2015) argues that interference occurs due to the process and result of language system intercommunication in bilingualism condition. (Weinrich, 1953) divided the kinds of interference into three; they are the transfer of element from one language to another, the application of elements that do not applicable to the second language into the native language, and the disobeying structure of second language due to there is no equivalent structure in the first language. He also divided the forms of interference into phonological interference, lexical interference, and grammatical interference. The grammatical interference includes morphological interference that absorbs the affixes from native language, and syntactical interference that undermines the sentence structure of the targeted language.

Furthermore, (Weinrich, 1953) divided the factors behind the existence of interference into structural and non-structural factors. The structural factors include the difference of linguistics systems in native language and the targeted language. The non-structural factor includes the learners' bilingualism, language loyalty, the inadequate vocabulary of learners' language, synonymy necessity, language pride, and the habits of using mother tongue language.

English as used by bilingual or multi-lingual people is commonly interfered by many factors. The most fundamental problem is the inclusion of the first language into the use of English. This interference gives a serious impact to the language produced. It seems weird when the speaker makes mistake dealing with the linguistic pattern, such as speech sound, grammatical structures and meaning. As a result, the listener should hardly catch the idea or even come to wrong conclusion. Hence, the language learners should comprehend the targeted language rules to convey their ideas easily. Nurul Jadid English learners commonly make mistakes in grammatical aspects, both morphological and syntactical structures although it may come to phonology and semantics as well.

This study focused on grammatical interference of English used by Nurul Jadid students. It relies on the assumption that native language's grammatical interferences are frequently produced by the English learners. This consideration arises from the observation on their daily communication during two months. The preliminary observation showed that the decrease of loyalty in using English structure has major effect on language interference. For instance, one of students said to his friend, "Don't know I am" shows intertwined interference (viewed from morphology and syntactical rule). The existence of double auxiliaries ( $d o$ and $a m$ ) in this statement indicates malformation of functional morpheme in verbal sentence. the speaker uses auxiliary am after $I$ to match the syllable of their first language (Madura: seng$\mathrm{koq} / \mathrm{seng}-\mathrm{ksq} /$ ) to English (I am /al-am/). Moreover, this statement has syntactical 


\section{VOL. 03 NO. 01, JUNE 2021}

interference from the first language to the targeted language (English), it is error in structure of predication. In English sentence, (Nelson, 1958) stated that the constituent of structure of predications are coming in subject and predicate order. On the contrary, in Madurese, the subject may come after verb, such as tak tao sengkoq $(V-S)$. this datum showed that the English used by the students is interfered by their native language. They tend to say "Don't know I am" instead of "I don't know".

By analysing the grammatical interference in English communication used by Nurul Jadid students, this study will highlight the kinds of grammatical interference occurs in students' communication and the factors. This analysis is considered significant because it attempts to bridge linguistics and social theories, linking considerations of language use and the language teaching.

Several studies conducted research related to grammatical interference on second or foreign language, such as (Erarslan \& Devrim, 2014), (Syarif, 2014), (Sarfraz, Mansoor, \& Tariq, 2016), (Galkina \& Radyuk, 2019), and (Septiana, 2020). They analysed the grammatical interference occurs in student's written text. However, grammatical interference also appears in communication, and there is still little research that analyses it in speaking. Some of them are (Susilowati, 2017) and (Ni'mah, 2018). They analyse the grammatical interference in Arabic language. It still has different research focus and setting. Therefore, the authors are interested in examining the grammatical interference in English communication used by Nurul Jadid Students.

\section{METHOD}

This study investigates the grammatical interference in oral English communication and its factors. It aims to reveal the use of specific language structures or particular words in English spoken. It also discusses the factors that affect the production of the interference. This study uses case study design. Case study research involves the study of case in real life, contemporary context or setting. This case may be a concrete entity, such as individual, a small group, an organization, or a partnership (Yin, 2014). Case study design is included into qualitative research, in which the researcher explores a real life, contemporary bounded system or multiple contemporary bounded systems over time, through detailed, in-depth data collection involving multiple sources of information (such as observation, interviews, audiovisual material, and documents and reports). The unit of analysis in the case study design can be multiple cases (a multisite study) or a single case (a within-site study) (Creshwell \& Poth, 2018).

Data are the core of the study and it serve as foundation for this research. The source of data of this study were respondents and documents. The respondents of this study were twenty students Nurul Jadid boarding school who stay in language program. The students are from several programs, they are ten students of FLDI (Foreign Language Development Institution), five students of BPK, and five students of LIPS (Language Intensive Program of SMP Nurul Jadid). The program choice is based on the number of achievement achieved by students in several competitions. Those institutions often win some language competition, so they can be called as pesantren pioneers in term of foreign language institution. Besides, the participants were selected on the basis that they have completed grammar class in their institution. This level was the highest level and described as a near native speaker level. The students are supposed to have adequate proficiency in speaking English. It means that they already have sufficient knowledge in mastering language structure and vocabulary. Although they were in high level of grammar, the interferences are still likely occurring in spontaneous communication. Documents are written information that contain important information that is collected from interview. In this study, documents are in the form of audio recording of students' conversation. 


\section{VOL. 03 NO. 01, JUNE 2021}

The data of this study is collected through two ways: oral task and interview. The oral task was a dialogue between two students about their daily habit. It was given in informal situation to create a comfortable atmosphere so that the students felt relaxed and can communicate fluently. The oral task was recorded for 10- 30 minutes and then transcribed for further analysis. After the oral task was done, the students were interviewed individually to explain why and how they used a specific first language structures in their English communication. The result of this interview was noted as the answer of second research problem, it is the factors of interference.

The data analysis procedures of this study involved reading transcripts from the oral tasks. Then all the data were grouped and categorized based on the grammatical interferences that is stated by (Weinrich, 1953). Weinrich identified the grammatical interferences involve morphological and syntactical interferences. After that, the researcher focused on the forms of grammatical interference in English communication and related it to the native language grammar to look forward the interference forms. The data from interview was used to support the obtained data. The last step is writing conclusion based on the whole analysis. The conclusion covered all the discussion of identification of grammatical interference in English communication used by students and its factors.

\section{FINDINGS AND DISCUSSION}

\section{Types of Grammatical Interference}

(Yusuf, 1994) in (Supriyanto, 2013) stated that the main factors of interference are the difference between the source of language and the target language. The differences including structure and the use of vocabularies. One of the data found that is interfered both structure and the vocabulary is:

\section{"Don't like that! That one just how?"}

This utterance showed a prohibition which means "Jhek enga' jiye! Ajiye pas dekremma?" in Maduries. This sentence is interfered by Maduries vocabulary that is translated into English literally. Besides, it is also interfered by Maduries sentence structure by omitting the auxiliary "be" before the word like to mean engak/seperti. This sentence also put the question word how in the last sentence while English interrogative sentence puts the question word in the beginning of sentence that is followed by auxiliary verb.

After analysing the data, it was indicated that the grammatical errors of students' communication in English were caused by strong interference of their first language. In the following, the researchers presented the interference in English sentence pattern produced by Nurul Jadid students by classifying them into several categories involving syntax, morphology, and literal translation.

\section{A. Syntax}

Based on the data analysis, there were some sub-indicators in the element of syntax. The sub-indicators including word order in structure of predication, warning expression, and interrogative pattern. The interrogative patterns are divided into positive interrogative, and negative interrogative.

\section{Structure of Predication}

(Nelson, 1958) and (Kim \& Sells, 2007) agree that the well-formed English sentence is coming in subject and predicate order. Each of these may be a single word, a word with function word(s), a phrase, or a clause. In line with that, the canonical pattern of Madurese sentence is also in subject + predicate order, which means the subject constituent comes before the predicate constituent. Nevertheless, due to the permutation process, the structure of both constituents can be reversed to be $\mathrm{P}+\mathrm{S}$ (Predicate + Subject) (Moehnilabib, Wahab, 
VOL. 03 NO. 01, JUNE 2021

Prijambada, Huda, \& Ghazali, 1979). The following examples illustrate the permutation process of Madurese sentence:

The canonical pattern Sēngkoq tak tao
Kanaq jereya nanges

I don't know

$\mathrm{S}+\mathrm{P}$

The child is crying $\mathrm{S}+\mathrm{P}$

Permutation pattern

Tak tao Sēngkoq
Nanges kanak jereya

Don't know I

$\mathrm{P}+\mathrm{S}$

Crying the child

$\mathrm{P}+\mathrm{S}$

In daily communication, Nurul Jadid students seem to use the permutation pattern of Madurese sentence which is different from English sentence pattern. The difference cause syntactical interference from Madurese to English. As it is shown:

1) Don't know also I am. (tak tao kèya sēngkoq)

There is interference from Madurese pattern in this sentence. When the speaker spoke in Madurese, the pattern of the sentence is predicate + subject or taq tao keya sēngkoq. Differing from this, English sentence pattern comes in Subject + predicate order. Hence, the sentence should be $I$ don't know, too. The existence of auxiliary am after morpheme $I$ is syllable adjustment of Madurese word sēngkoq (two syllables) to English word I am (al-aem), whereas the sentence is verbal sentence which do not need verb-to be.

2) Wanna eating I am. (terro ngakanah sēngkoq)

3) Afraid I am. (takoq sēngkoq)

The interference of sentence (2) is not only in the syntactical structure, but also in morphological aspect, especially in misplacing the functional morpheme. The pattern used in this sentence is similar to the previous discussion. It is predicate + subject. The English utterance should be I want to eat or I wanna eat (informal speaking) without the functional morpheme -ing and am. The structure of sentence (3) is also interfered by Madurese sentence structure which is different from English structure. This sentence is called nominal sentence that needs auxiliary as the predicate. The speaker placed the subject and predicate after adjective word. The sentence should be I am afraid.

4) On the first time I come of, good so much I think, bust actually the worse.

5) Funny so much you. (locoh sara bāqna)

$$
\text { (Mapan sara pèkkèr sēngkoq) }
$$

Sentence structure of (4) and (5) are also interfered by Madurese sentence structure. The interference is not only in the syntactical structure, but in morphological aspect. Since these sentence is nominal sentence, they miss the functional free morpheme. In English, sentence (4) should contains noun clause. It should be I think it (the performance) is good. it is good is a noun clause as direct object of the predicate think. However, this sentence is interfered by Madurese sentence that come in predicate+ subject order. Mapan sara is adjective phrase as direct object of the word pèkkèr, and the word pèkkèr is predicate of subject sēngkoq. Thus, the syntactical structure of this sentence is:

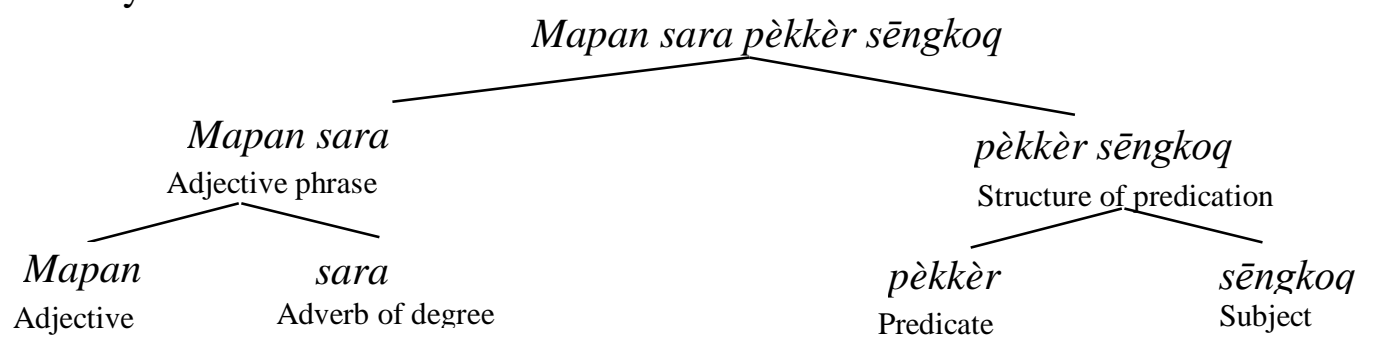

Figure 1. Tree diagram of Madurese syntax 
If we refer to the canonical pattern of Madurese sentence, the pattern should be sengkoq pèkkèr mapan sara. The adjective phrase mapan sara modifies the word performance that is not mentioned in that sentence. In English, semantically, the head of modifier should be stated clearly so the listener is able to understand what the speaker means. Hence, the sentence good so much I think miss the structure of noun clause to be well-formed English sentence.

Sentence (5) is an English nominal sentence which is also interfered by Madurese sentence structure. The nominal sentence is a sentence which its predicate is not a verb but noun, adjective, or adverb (Suryanto, Hikmah, \& Pranata, 2019) such as the snake is alive. Alive is predicative adjective that completes the linking verb is and modifies the subject the snake. Nominal sentence requires the structure of subject, linking verb, and predicate order. The sentence "funny so much you" is literal translation from Madurese sentence locoh sara bāqna. In Madurese, this sentence is fully grammatical which has pronoun bāqna and adjective locoh. It satisfies the sentence requirements of having a subject and adjective phrase as predicate. However, in English, it is ungrammatical construction. To modify the subject, the adjective phrase need linking verb. Therefore, the English sentence of locoh sara bāqna should be you are funny so much or you are so funny.

\section{Active-interrogative sentence}

In forming an English interrogative sentence, (Nelson, 1958) explained the form of interrogative sentence is marked by a change in word order by inverting the structure of the subject and the auxiliary, such as he is working. $\rightarrow$ is he working? Verbs which have no auxiliary in the affirmative sentence use the auxiliary do/does/did to form the interrogative sentence like he works $\rightarrow$ does he work?

On the other hand, Madurese language does not have any auxiliaries in its sentence. To form a negative and interrogative sentence, it needs constituent question like apa, arapa, bilâ, sapa, kemma, dimma, dâ'emma and question mark. Some interrogative sentences in Madurese do not need constituent question, yet it still need question mark like Bâqna ngakan? (Sofyan, 2008). The different of these concepts influence the emergence of interference in English communication used by Nurul Jadid students which is caused by Madurese language dominance as their first language. This interference is known from the contrastive analysis by comparing the sentence structure in English and Madurese.

6) Where to go, you? (dâ' emmaa bâqna?)

7) What the name? (apa nyamanah?)

8) In where you put? (è dimma bâqna nyabek?)

9) What you write? (apa se è toles?)

10) Tomorrow what day? (lagg ${ }^{h}$ unah are apa?)

The above sentences (6-10) do not use auxiliary in forming the interrogative sentence. As it is explained that English sentence has two kind of sentences; they are nominal sentence and verbal sentence. In forming an interrogative sentence, the speaker also needs to notice the form of the sentence whether it is nominal or verbal. Verb which has no auxiliary in the affirmative sentence is mentioned as verbal sentence. It needs auxiliary do/does/did to form the interrogative sentence. Sentence 6), 8), and 9) are verbal sentence because the predicate is verb like go, put, and write. Since the subject is second-person pronoun 'you', this sentence needs auxiliary ' $d o$ ' to form the interrogative. Furthermore, the interrogative sentence also inverses the structure of subject and auxiliary so the auxiliary comes before the subject. the interrogative sentence should be "where do you go? (6)", "where do you put? (8)", and 


\section{VOL. 03 NO. 01, JUNE 2021}

"what do you write? (9)". The unique thing is the existence of preposition 'in' before question word in sentence 8) which is interfered by Madurese structure. The speaker spoke "in where" as the literal translation of phrase "e dimma". The particle " $e$ " in Madurese refers to preposition " $d i$ " in Bahasa Indonesia which is translated into "in" in English, whereas the word "where" refers to place or location without any additional preposition.

Furthermore, sentence 7) and 10) also interfered by Madurese structure. The error is omitting auxiliary in forming the interrogative sentence for a nominal sentence. The sentence "what the name" is literal translation of "apa nyamanah", it should be "what is the name or what is its name?"

\section{Negative-interrogative sentence}

English interrogative sentence has two forms, it is affirmative and negative. The affirmative interrogative is by changing the word order of subject and auxiliary as explained above, while negative interrogative sentence is marked by the insertion of the special function word not immediately after the first auxiliary. The use of auxiliary do follows the same pattern of affirmative interrogative sentence. In negative-interrogative structure, two elements are inserted into the split of verb-phrase (Nelson, 1958) as shown in Figure 2.

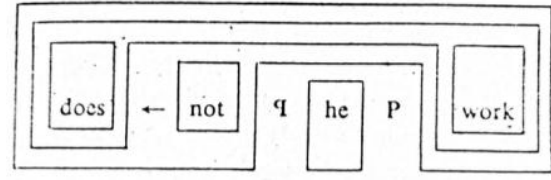

Figure 2. Chinese box of negative-interrogative sentence

Similarly, the negative sentence in Madurese also inserts the negative function word like enjâ', bânnè, and jhâ' in a sentence. These words can be categorized as non-referential word because they do not refer to a particular reference. Moreover, these words only have meaning when it is associated with other linguistics constituent (Sofyan, 2008). However, the form of Madurese negative sentence and English differs in the use of auxiliary. This difference leads to the interference in students' English communication as the data below.

11) Not see in calendar you? (ta' nyunguk e kalender, ben?)

12) You not hungry? (bâqna ta' lapar?)

13) Why you not bring? (arapa bâqna mak ta' ngibeh?)

Sentence 11)-13) shows error in the structure of English negative interrogative. Sentence 11) has two kinds of error, it is the position of subject "you" and missing the auxiliary. The subject should be after the word "not" and before it should be an auxiliary. Hence, the structure should be Aux + not $+\mathrm{S}+\mathrm{VP}=$ do not you see in calendar? Sentence 13) has the same case with sentence 11). On the other hand, sentence 12) is a nominal sentence which has different auxiliary from verbal sentence, but in the same structure. The sentence should be "are not you hungry?"

\section{Imperative Sentence}

English imperative sentence consists of predicates that only contain verb in infinitive form. The implied subject in imperative sentence is " $y o u$ ", and it is usually marked by exclamation mark. It sometimes adds the word "please" before the exclamation mark. The structure of imperative sentence is Verb+ Complement. This structure is similar to Madurese sentence, but some Madurese speaker add the word " $y a \hat{h} h$ " to emphasize the action. Hence it influences to the students' English communication.

14) Be honest, yes! (se j'ujur yâ!) 
15) Watch out, yes! (senga' yâ!)

16) Watch out you stealing my money again! (senga' bâqna ngico’ tang pèsè pole)

17) Up to you la!

18) Eat la! don't know I am.

Sentence 14) and 15) are clearly interfered by Madurese communication that adds " $y a \hat{h} h$ " to emphasize the action in imperative sentence. In Madurese language, " $y \hat{a}$ " belongs to particle that is used in imperative and warning expression when the speech partner does not do the action that the speaker wants or doesn't want, but, it is possible to violate orders or perform actions that the speaker doesn't want (Sofyan, 2007). Hence the particle yâ is used to emphasize the action from the speaker to the speech partner.

Sentence (16) shows a literal translation from L1 into L2. The English statement should be "Don't try to steal my money anymore". The interference of that sentence is detected from the grammatical structure. It seems just combining a word by word so that it truly wrongs and sounded weird. Commonly, In English context people use word "Don't" to state an attention term repeatedly and negatively and ended by "anymore" word.

Meanwhile, sentence (17) and (18) seems to use the L1 affixes. However, "la" is not suffix that attaches the base word. It is a particle that stands alone. In English, particle is related to preposition and lexical verb to produce the phrasal verb. Particle "la" in Madurese is used when the speech partner does not heed the speaker's commands or prohibition in several times, so the speaker feels discouraged or annoyed (Sofyan, 2007). This particle represents the speaker's emotional level towards the attitude or opinion of the speech partner.

\section{B. Morphology}

Morphological interferences are made when the morphological aspect in a sentence is being tainted, or misinformed. Morphology involves the relation on how words are formed and fits together. Based on preliminary observation it was found that most the students often overgeneralizing the morphological form of L1 into L2. It means that they create similar structure of L1 and L2. The data are categorized into morpheme omission and mother-tongue affixes.

\section{Omitting morpheme}

Morpheme is the smallest meaning of morphology. It has two types, free and bound morpheme. Free morpheme is the root that can stand by itself. It also divided into two types, lexical morpheme and functional morpheme. Lexical morpheme involves noun, verb, adjective, and adverb. Functional morpheme includes pronoun, article, conjunction, preposition, determiner, auxiliary, and interjection. In this study, the morphological interference found in the absence of functional morpheme like auxiliary, pronoun, and determiner.

19) Don't like that. (jhâ' dekye.)

20) A: Do you like mathematics?

B: Not so! Because I like science, is not mathematics. (Enjâ'! polanah sēngkoq sen $^{n}$ eng IPA, bânnè matematika.)

21) When presenter competition, I was _ actor of Ibrahim movie. (Bekto lomba acaca, sēngkoq ded ${ }^{h}$ i aktor e filem Ibrahim)

Based on L1 meaning, the word like in sentence 19) is an adjective. Madurese language does not have any additional particle in expressing adjective. Differing from this, English sentence needs auxiliary before adjective. Hence, in sentence 19), auxiliary be before the word like is missing, the sentence should be Don't be like that. 


\section{VOL. 03 NO. 01, JUNE 2021}

Sentence (20b) contain negation meaning. In Madurese the negation words involve enjâ, bânnè, and jhâ'. The words enjâ' and bânnè are produced as the denial answer of a question or to confirm a negative statement. Both can be produced as independent morpheme that stand as a sentence, or together with other constituent (Sofyan, 2008). Based on this rule, the English learner often translate the words enjâ' and bânnè into isn't. The phrase isn't is incomplete structure in English sentence because it does not have subject. The constituent omit pronoun "it" as its subject.

Furthermore, sentence 21) also interfered by Madurese structure. The use of article in Madurese sentence only come along with adjective word (Sofyan, 2008), like sè rad in (which is beautiful), so the speakers do not use article or determiner before noun and personal noun. It influences the English sentence that they produce. It shows that sentence 21) omit the functional morpheme for its language interference.

\section{Using Mother-tongue affixes}

Besides free morpheme, morphology also discusses the bound morpheme in English word. The bound morpheme has two kinds, inflection and derivation. Verhaar in (Supriyanto, 2013) explains that inflectional morpheme is the change of morpheme that maintain the lexical form of a word. In English, the inflection is usually marked by suffixes such as cat $+s$ ("s" is the plural form of noun), mention + ed ("ed" is a mark of past form of regular verb). Furthermore, the derivational morpheme is the change of morpheme that produced different lexical identity, such as white (adjective) $+i n g=$ whitening (verb). Differing from English, Madurese sentence only has derivation for its bound morpheme. The derivation involves all kind of language affixes that attaches to the base word (Moehnilabib, Wahab, Prijambada, Huda, \& Ghazali, 1979). This difference causes the students use their mother-tongue's affixes into English base word as it is showed in the data below.

\section{2) How much-an is that?}

Sentence (22) uses suffix -an for the phrase how much. (Marsono, 2016) explained the suffix - an in Madurese language refers to indefinite plural morpheme. It means that the speaker tells indefinite amount of something. In the context of sentence (22), the speaker asks the price for several things so he use - an after the word much. In English context, the speaker should say how much are they?

\section{The Factors behind the Grammatical Interference}

The grammatical interferences of Madurese into English communication used Nurul Jadid students are influenced by several factors. They are:

learners' bilingualism, language loyalty, the inadequate vocabulary of learners' language, synonymy necessity, language pride, and the habits of using mother tongue language

\section{a. Learners' Bilingualism}

Based on the data analysis, the factor of Nurul Jadid students' interlingua transfer involves morphology and syntax. This is caused by the existence of language contact between first language to the targeted language which has different language system. For instance, the sentence structure of English and Madurese is different, especially for the subject and predicate order. Besides, the different of morpheme and particle usage in these languages cause barrier in studying a new language. Hence the interference often appears in speaking the new language.

\section{b. Language loyalty}




\section{VOL. 03 NO. 01, JUNE 2021}

The lack of bilingualism's loyalty to the targeted language tends to lead the learners to the negative attitude toward the use of targeted language in their communication. This causes the uncontrolled neglect of the targeted language rules. The data found explored the Madurese structures that is still used by the students in speaking English for their daily communication. The students' disloyalty on language rule usage appears in English sentence structure and its morpheme.

\section{c. Synonymy necessity}

Since every language has synonymy in its meaning, the language users often make interference in the form of absorption or borrowing the structure order of their first language to produce synonymy in the targeted language.

\section{d. The Learners' Habit}

Based on the preliminary interview to Nurul Jadid students, the interference in their English communication is caused by their habit in using their first language in their living town. It affects their skills in producing the well-formed English sentences. For instance, the students often produce English sentence in Madurese structure.

\section{CONCLUSION}

Based on the overall description and analysis of grammatical interference in English communication used by Nurul Jadid students, it can be concluded into 1) the interference in English communication occurs in morphological and syntactical aspects. The syntactical aspect involves the inversion of subject and predicate order, the absence of modal auxiliary in forming the interrogative sentence, and the use of first language particle in English imperative sentence. Furthermore, the morphological aspect involves omitting English morpheme and the use of first language affixes. 2) the factors behind the grammatical interference of English communication used by the students involve learners' bilingualism, language loyalty, synonymy necessity, and the learners' habit. Based on the interview conducted on twenty students of Nurul Jadid boarding school, these factors have a big impact to the occurrence of grammatical interference in English communication used by the students.

\section{REFERENCES}

Abrar, M., Mukminin, A., \& Habibi, A. (2018). "If our English isn't a language, what is it?" Indonesia EFL Student Teacher Challenges Speaking English. The Qualitative Report, $129-145$.

Budiarti, A. (2013). Interferensi Bahasa Indonesia ke dalam Bahasa Inggris. BAHASA DAN SENI, 10-17.

Creshwell, J. W., \& Poth, C. N. (2018). Qualitative Inquiry \& Research Design: Choosing Among Five Approaches. United Kingdom: SAGE Publication India Pvt. Ltd.

Erarslan, A., \& Devrim, H. (2014). Language Interefrence on English: Transfer on the Vocabulary, Tense and Preposition Use of Freshman Turkish EFL Learners. ELTA Journal, 4-22.

Galkina, A., \& Radyuk, A. V. (2019). Grammatical Interference in Written Papers Translated by Russian and American Students. Training, Language and Culture, 89-102.

Kim, J.-B., \& Sells, P. (2007). English Syntax: An Introduction. Center for the Study of Language and Information.

Marsono. (2016). Morfologi Tujuh Bahasa Anggota Rumpun Austronesia dalam Perbandingan. Yogyakarta: Gajahmada University Press. 
Moehnilabib, M., Wahab, A., Prijambada, S., Huda, N., \& Ghazali, A. (1979). Morfologi dan Sintaksis Bahasa Madura. Jakarta: Pusat Pembinaan dan Pengembangan Bahasa.

Nelson, F. W. (1958). The Structure of American English. New York: Ronald Press Company.

Ni'mah, J. (2018). Interferensi Gramatikal Bahasa Indonesia dalam Maharah Kalam Santriwati KMI Pondok Modern Ar-Risalah Ponorogo. Lisania: Journal of Arabic Education and Literature, 121-137.

Razaq, H. (2019, December 21). Pondok Pesantren Nurul Jadid Beri Pendidikan Bahasa Asing. (Z. A. As'ad, Interviewer)

Sarfraz, S., Mansoor, Z., \& Tariq, R. (2016). Analysis of Grammatical Interference and its Social Acceptability in Pakistani Context. Procedia-Social and Behavioral Sciences, 684-688.

Septiana, A. R. (2020). The Indonesian Grammatical Interference on EFL Students' Writing. Journal of Research on English and Language Learning, 46-52.

Shumin, K. (2002). Factors to Consider: Developing Adult EFL Students Speaking Abilities. Methodology in Language Teaching: An anthology of current practices, 204-211.

Sofyan. (2007). Beberapa Keunikan Linguistik Bahasa Madura. Humaniora, 232-240.

Sofyan, A. (2008). Tata Bahasa; Bahasa Madura. Sidoarjo: Balai Bahasa Surabaya.

Sugeha, A. Z. (2017). Variasi Pilihan Bahasa pada Masyarakat di Kabupaten Probolinggo: Kajian Etnografis. Etnolingual, 125-144.

Supriyanto, R. A. (2013). Grammatical Interference from English into Indonesian Language Made by English Native Speakers in Salatiga. Register Journal, 271-289.

Suryanto, B. T., Hikmah, D., \& Pranata, M. S. (2019). English Time: Designed for NonEnglish Students. Probolinggo: Pustaka Nurja.

Susilowati, D. (2017). Aktualisasi Interferensi Bahasa Daerha dalam Bertutur Kata pada Pembelajaran Bahasa Indonesia di Sekolah. Edunomika, 57-66.

Syarif, H. (2014). Grammatical Interference Patterns in the English Departments students' Writing: Indonesian to English Grammar. Applied Linguistics, 22647-22649.

Tom, A. A., Johari, A., Rozaimi, A., \& Huzaimah, S. (2013). Factors Contributing to Communication Apperehension among Pre-University Students. Academic Journal of Interdiciplinary Studies, 665-669.

Vavilova, E. N., Korneeva, M. A., \& Quy, N. N. (2015). Genre Interference in the Process of Foreign Language Speaking Training. Procedia - Social and Behavioral Sciences, 225-230.

Weinrich, U. (1953). Language in Contact: Finding and Problem. New York: Mounton Publishers.

Yin, R. (2014). Case Study Research: Design and Method (5th ed). Thousand Oaks, CA: SAGE.

Yusuf, S. (1994). Teori Terjemah: Pengantar ke Arah Pendekatan Linguistik dan Sosiolinguistik. Bandung: Mandar Maju. 